E3S Web of Conferences 1, 03003 (2013)

DOI: $10.1051 / \mathrm{e} 3$ sconf/20130103003

(C) Owned by the authors, published by EDP Sciences, 2013

\title{
A Study of Heavy Metals Pollution in Italy with the Atmospheric Modelling System of the MINNI project
}

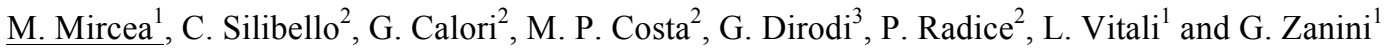 \\ ${ }^{1}$ UTVALAMB-AIR laboratory, National Agency for New Technologies, Energy and Sustainable Economic \\ Development (ENEA), Via Martiri di Monte Sole 4, Bologna 40129, ITALY, mihaela.mircea@enea.it \\ 2 ARIANET Srl, Via Gilino 9, Milan 20128, ITALY, c.silibello@aria-net.it \\ ${ }^{3}$ Italian Ministry of Environment, Territory and Sea, Department of Environmental Protection, Via Cristoforo Colombo \\ 44, Rome 00147, ITALY, dirodi.mariagesuina@minambiente.it
}

\begin{abstract}
This work shows preliminary results for heavy metals concentrations simulated with the atmospheric modelling system (AMS) of the MINNI project. The simulation has been carried out for the year 2005 with a horizontal resolution of $25 \mathrm{~km}$. The simulated concentrations of $\mathrm{As}, \mathrm{Cd}, \mathrm{Ni}$ and $\mathrm{Pb}$ have, in general, the highest values in urban and industrial areas and compare well with available measurements.
\end{abstract}

Key words: Heavy metals, air quality modelling, model validation.

\section{Introduction}

Heavy metal pollution has both natural and anthropogenic sources. Soil erosion, volcanoes, sea and natural vegetation through leaching from leaves and stems, decomposition and volatilization, release heavy metals into the atmosphere. Industrial sources such as active and closed mining sites, foundries and smelters, combustion by-products and traffic release directly heavy metals in the atmosphere and also contribute indirectly to the contamination of soils, rivers and lakes through the wet and dry deposition processes. The contaminated soils and waters contribute further to the increase of heavy metals concentrations in atmosphere through the wind-blown dust and evaporation. In a similar way, the agriculture, through the use of the inorganic and organic fertilizers which contains heavy metals, is an atmospheric source of such pollutants.

Some heavy metals such as $\mathrm{Hg}, \mathrm{Ag}, \mathrm{Pb}, \mathrm{Ni}$ are highly toxic elements (Nieboer and Richardson, 1980) while others such as $\mathrm{Fe}, \mathrm{Cu}$ and $\mathrm{Zn}$ are essential for plants and animals (Wintz et al. 2002). Cd, $\mathrm{Hg}$ and As are strongly poisonous to metal-sensitive enzymes, resulting in growth inhibition and death of organisms. Heavy metals are persistent in the environment and are subject to bioaccumulation in food-chains determining various diseases in human beings. Cadmium has been identified as a potential human carcinogen, causing lung cancer and exposure to it is also associated with kidney and bone damage. Lead exposures have developmental and neurobehavioural effects on foetuses, infants and children, and elevate blood pressure in adults. Mercury is toxic in the elemental and inorganic forms, but the main concern is associated with the organic compounds, especially methylmercury, that accumulate in the foodchain, i.e. in predatory fish in lakes and seas, as these are the main routes of human exposure (WHO Report, 2007).

Although the concentrations of heavy metals in the air are low, their contributions to the environment through the deposition processes are not negligible and is affecting ecosystems and human population. The origin and the fate of heavy metals in the atmosphere are subject to complex interactive processes such as emissions, transport and dispersion, dry and wet removal that can be described by means of air quality models. The air quality model FARM (Silibello et al., 2008), part of the atmospheric modelling system of the MINNI project, has been extended to take into account the heavy metals behaviour and applied to the year 2005. This study shows preliminary results on the air pollution levels of $\mathrm{As}, \mathrm{Cd}$, $\mathrm{Ni}, \mathrm{Pb}$ over Italy, including the islands Sicily and Sardegna, and a comparison of model results against the available measurements.

\section{Methods and Materials}

Description of AMS and of simulation set up

MINNI (Mircea et al., 2010) is the Italian Integrated Assessment Modelling System for supporting the 
International Negotiation Process on Air Pollution and assessing Air Quality Policies at national/local level sponsored by the Italian Ministry of the Environment. The MINNI system comprises an Atmospheric Modelling System (AMS) and an integrated assessment model, the Greenhouse Gas and Air Pollution Interactions and Synergies Model over Italy (GAINS-Italy). The main components of AMS are the meteorological model RAMS (Cotton et al., 2003), the emission processor and the Flexible Air quality Regional Model FARM, for simulating the atmospheric chemistry. Three-dimensional Eulerian chemical-transport model FARM was modified in order to include heavy metals following Travnikov and Ilyin (2005). The aerosol model considers the particles subdivided in two fractions: fine and coarse and takes into account condensation processes of inorganic species leading to the formation of ammonium nitrate and ammonium sulphate from their gaseous precursors: $\mathrm{NH}_{3}$, $\mathrm{HNO}_{3}$ and $\mathrm{H}_{2} \mathrm{SO}_{4}$. Coagulation and nucleation processes as well as secondary aerosol formation are not accounted for. Heavy metals are characterized by very low volatility; therefore the model assumes that they are transported in the atmosphere only attached to fine aerosol particles. Chemical transformations of these pollutants are not considered.

The simulations has been carried out for the year 2005 with a spatial resolution of $20 \mathrm{~km} \mathrm{x} 20 \mathrm{~km}$ and 16 terrain-following levels irregularly spaced from the ground to $10000 \mathrm{~m}$ above surface level, with the first four layers placed at 20, 75, 150 and $250 \mathrm{~m}$. The meteorological input fields to FARM have been produced with the prognostic, non-hydrostatic meteorological model RAMS, run in a 2-way nested grids configuration: an outer grid covering large part of Central Europe and the Mediterranean Sea, with a horizontal resolution of 60 $\mathrm{km} \times 60 \mathrm{~km}$, and an inner grid, including the Italian domain for the air quality simulations, with a resolution of $20 \mathrm{~km} \times 20 \mathrm{~km}$. Initial and boundary conditions and data assimilation have been based on mesoscale analyses produced by means of the RAMS pre-processor ISAN (ISentropic ANalysis), with a time frequency of 1 hour. ECMWF analyses, available every 6 hours with a horizontal space resolution of 0.5 degrees, have been used as background fields. WMO (World Meteorological Organisation) SYNOP and METAR surface observations, retrieved from ECMWF archives and available with time frequency of 1 hour, have been used as assimilated data. A nudging technique has been employed by RAMS to assimilate data analyses during the whole model simulation through an additional forcing term to the conservation equations for pressure, temperature, water vapour and momentum. The sea surface temperature has been defined on a daily basis from data included in ECMWF operational analyses. At the start of every simulation week, RAMS has been re-initialized with ECMWF analyses and surface observations to avoid shortcomings due to possible errors in input data, growing with simulation time.

The emissions used in this study are the National
Emissions Inventory developed by ISPRA using a topdown approach (ISPRA, 2009) for the national territory and the EMEP/MSC-E inventory for the surrounding countries based on official data received from the EMEP Centre on Emission Inventories and Projections (CEIP) [http://www.ceip.at]. The ISPRA inventory is compiled at national level, and then disaggregated at provincial level (NUTS3) using activity-related proxy data.

In the inventory, emissions of $\mathrm{NO}_{\mathrm{X}}, \mathrm{SO}_{\mathrm{X}}, \mathrm{PM} 10$, $\mathrm{CO}, \mathrm{NMVOC}$, POPs and HMs are associated to point and diffuse sources, subdivided by activity sectors. Point sources (mostly large industrial facilities and energy production plants) are individually characterized with geographic coordinates, physical and thermodynamic parameters (stack height and diameter, gas exit velocity and temperature). Related emissions are either directly measured or estimated through process-specific EF starting from fuel consumptions or activity levels and accounting for abatement techniques that can be in place. Diffuse sources are all other sources that cannot be considered on an individual basis and whose activities take place over a larger area; their emissions are usually estimated through statistical data of the underlying activities.

Heavy metals emissions related to dust suspension from soil and sea-salt aerosols have been included in the simulations following Travnikov and Ilyin (2007). Wind re-suspension of particles from these surfaces has been estimated using Vautard et al. (2005) and Zhang et al. (2005). The content of HMs in erodible soils has been estimated by using detailed measurement data on HMs concentration in top soil from the Geochemical Atlas of Europe developed under the auspices of the Forum of European Geological Surveys (FOREGS) [www.gtk.fi/ publ/foregsatlas/]. An optimal interpolation method has been applied to obtain spatial distribution of heavy metal concentration in soil. For areas not covered by the Atlas, defaults HMs concentration in soils and EF for suspension of sea-salt aerosol have been taken from Travnikov and Ilyin (2007). Boundary conditions (BCs) have been derived from continental scale simulation results at $50 \mathrm{~km}$ horizontal resolution provided by EMEP models for the year 2005. Three-hourly EMEP/MSC-W modelled concentration fields were used to provide $\mathrm{BCs}$ for the acidifying species considered by the chemical mechanism, while sixhourly EMEP/MSC-E model results were used to provide $\mathrm{BCs}$ for heavy metals $(\mathrm{Pb}, \mathrm{Cd}, \mathrm{As}, \mathrm{Ni})$.

\section{Results and Discussion}

Figure 1 shows the annual averaged concentrations of As, $\mathrm{Cd}, \mathrm{Ni}$ and $\mathrm{Pb}$ simulated and measured at the monitoring stations. The comparison takes into account only the stations that have data coverage for more than half of the year. It can be noted that only the stations located in Piedmont region fulfil this criterion limiting therefore a comprehensive validation of the model. The simulations shows that the highest concentrations of heavy metals in 


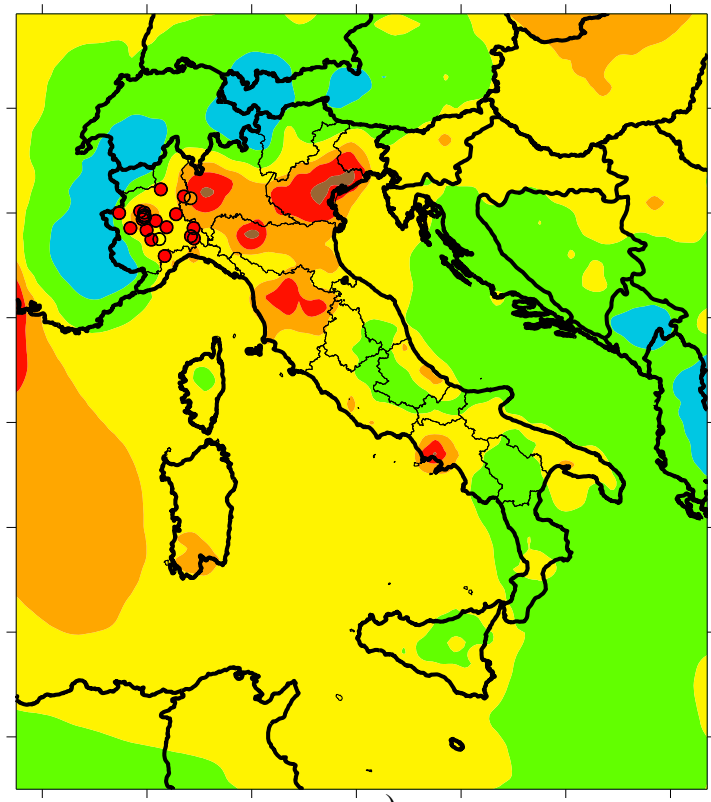

a)

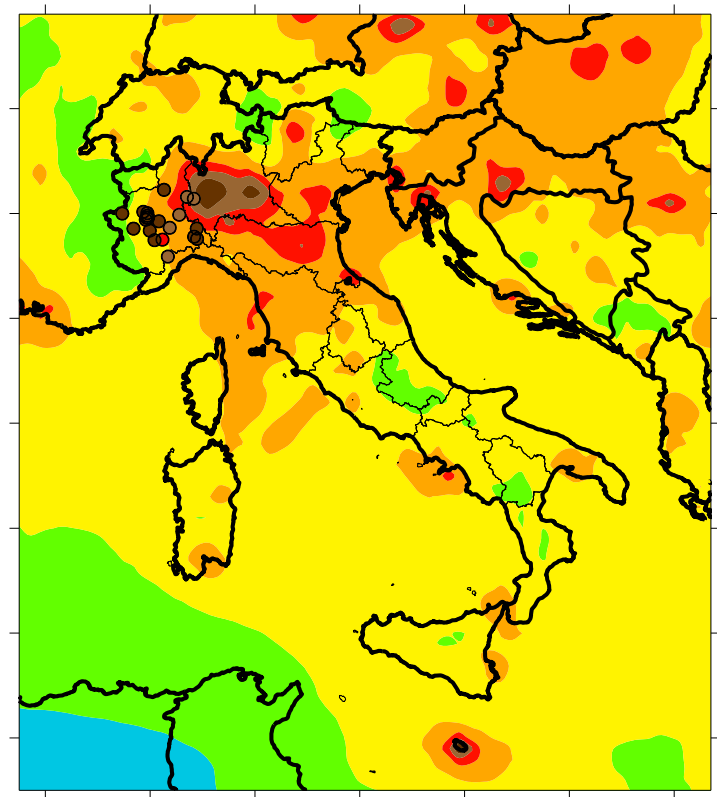

c)

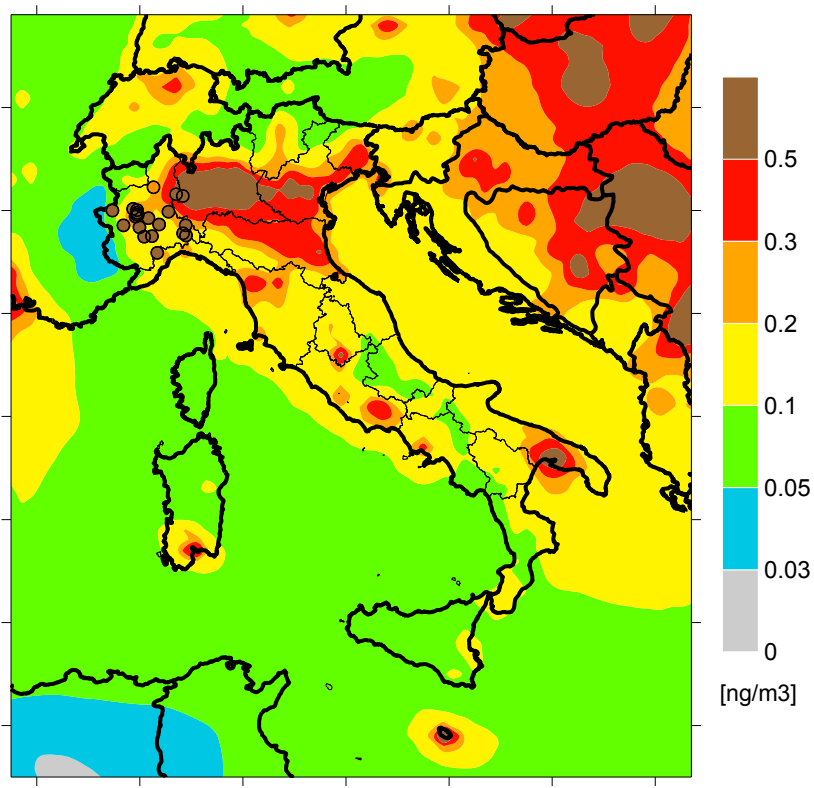

b)

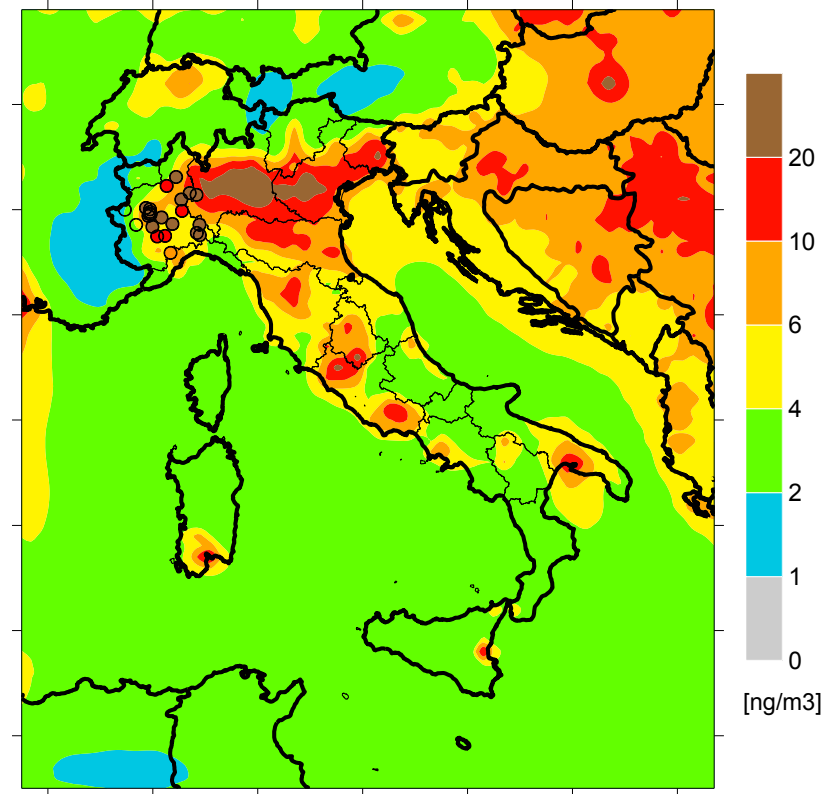

d)

Fig. 1. Annual averaged concentrations simulated and measured at stations (dots) for $\mathrm{As} \mathrm{(a),} \mathrm{Cd}(\mathrm{b}), \mathrm{Ni}(\mathrm{c})$ and $\mathrm{Pb}(\mathrm{d})$.

occur in the Po Valley, in cities such as Rome, Naples, Taranto and in industrial areas such as Termi, Taranto and Priolo. According to the simulation, only three areas the Po Valley have concentrations close to $6 \mathrm{ng} / \mathrm{m}^{3}$, the target value requested by EC Directive (2004/107/EC, 2004) for As, while the simulated concentrations of $\mathrm{Cd}$ (Fig. 1b) and $\mathrm{Pb}$ (Fig. 1d) are largely below the target values of $5 \mathrm{ng} / \mathrm{m}^{3}(2004 / 107 / \mathrm{EC}, 2004)$ and $0.5 \mu \mathrm{g} / \mathrm{m}^{3}$ (2008/50/EC, 2008), respectively. The simulation and the available monitoring data indicate concentrations of $\mathrm{Ni}$ in excess of the $20 \mathrm{ng} / \mathrm{m} 3$ level established by EC Directive (2004/107/EC, 2004) around Turin and Milano urban areas.

The comparison of simulated concentrations (map) with those measured at different sites (circles) shows a relative good reproduction of the spatial structure of concentration levels by model. However, further investigations will be performed in order to assess the effect of the spatial resolution, uncertainties in emissions and measurements representativeness.

\section{Conclusion}

The results of this first simulation over the Italian territory for the year 2005 show that the atmospheric modelling system of the MINNI project is able to simulate realistic concentrations of heavy metals. However, more observations, for longer periods and 
covering the whole country, are necessary for a comprehensive validation of model results.

\section{Acknowledgements}

This work is part of the MINNI (Integrated National Model in support to the International Negotiation on Air Pollution) project, funded by the Italian Ministry for Environment and Territory and Sea and carried out by ENEA. The authors wish to thank Ilia Ilyin, Marina Varygina and Alexey Vladimirovich Gusev (EMEP MSC-E) and Anna Carlin Benedictow and Michael Gauss (EMEP MSC-W) for providing EMEP models output. The authors also thank Beatrice Bondanelli (Autonomous Province of Bolzano), Monica Angelucci (Environmental Agency of Umbria Region), Sandro Zampilloni (Lazio Region), Carla Contardi (Piemonte Region), Fulvio Stel (Environmental Agency of Region Friuli-Venezia Giulia), Giuseppe Onorati (Campania Region), Salvatore Patti (Environmental Agency of Veneto Region) for supplying monitoring data.

\section{References}

Cotton, WR, Pielke, RA, Walko, RL, Liston, GE, Tremback, CJ, Jiang, H, McAnelly, RL, Harrington, JY, Nicholls, ME, Carrio, GG, McFadden, JP. RAMS 2001: Current status and future directions. Meteorology and Atmospheric Physics 2003; 82: 529.

Council Directive 2008/50/EC of the European Parliament and of the Council of 21 May 2008: On ambient air quality and cleaner air for Europe (The Framework Directive). From the Official Journal of the European Communities, 11.06.2008, En. Series, L152/51.

Council Directive 2004/107/EC of the European Parliament and of the Council of 15 Dicember 2004: Relating to arsenic, cadmium, mercury, nickel and polycyclic aromatic hydrocarbons in ambient air (Fourth Daughter Directive). From the Official Journal of the European Communities, 26.1.2005, En. Series, L 23/3.

ISPRA, 2009. La disaggregazione a livello provinciale dell'inventario nazionale delle emissioni. Anni 1990-1995-2000-2005. Rapporti 92/2009 ISPRA ISBN 978-88-448-0392-6 (in Italian).

Mircea, M, Zanini, G, Briganti, G, Cappelletti, A, Pederzoli, A,Vitali, L, Pace, G, Marri, P, Silibello, C, Finardi, S, Calori, G. Modeling air quality over Italy with MINNI atmospheric modeling system: from regional to local scale. Proceedings of $21^{\text {th }}$ Air Pollution Modeling and its Application, September 27 - October 1, 2010, Turin, Italy: 491-498.

Nieboer E, Richardson DHS (1980) The replacement of the nonde-script term heavy metals by a biologically and chemistrysignificant classification of metal ions. Environ Pollut Series B 1:3-26.

Silibello, C, Calori, G, Brusasca, G, Giudici, A, Angelino, E, Fossati, G, Peroni, E, Buganza, E. Modelling of PM10 concentrations over milano urban area using two aerosol modules. Environmental Modelling and Software 2008; 23: 333-343.

Vautard R., Bessagnet B., Chin M., Menut L. On the contribution of natural Aeolian sources to particulate matter concentrations in Europe: Testing hypotheses with a modeling approach. Atmospheric Environment 2005; 39: 3291-3303.

Travnikov O., Ilyin I. Regional Model MSCE-HM of Heavy Metal Transboundary Air Pollution in Europe. EMEP/MSC-E Technical Report 6/2005, 59 pp.

Travnikov O. Ilyin I. Modelling of heavy metals atmospheric dispersion in europe. Meteorological Synthesizing Centre - East of EMEP, May 2007.

WHO Report, Health risks of heavy metals from longrange transboundary air pollution. 2007; WHO Regional Office for Europe, Scherfigsvej 8, DK2100 Copenhagen Ø, Denmark, ISBN 97892890 71796.

Wintz H, Fox T, Vulpe C. Responses of plants to iron, zinc and copper deficiencies. Biochem. Soc. Tran. 2002; 30:766-768.

Zhang KM., Knipping EM., Wexler AS., Bhave PV., Tonnesen GS. Size distribution of sea-salt emissions as a function of relative humidity. Atmospheric Environment 2005; 39: 3373-3379. 